\section{Preoperative epidural administration of morphine or methadone for analgesia in female dogs undergoing to ovariohysterectomy}

\author{
Administração epidural pré-operatória de metadona ou morfina \\ para analgesia em cadelas submetidas a ovário-histerectomia
}

Fernanda Vieira Henrique*, Roberta Nunes Parentoni², Lylian Karlla Gomes de Medeiros ${ }^{3}$, Arthur Willian de Lima Brasil2 ${ }^{2}$ Kalyne Danielly Silva de Oliveira ${ }^{4}$, Renato Otaviano do Rego ${ }^{5}$, Almir Pereira de Souza ${ }^{6}$ \& Pedro Isidro da Nóbrega Neto ${ }^{6}$

'Médica-veterinária, MSc, Doutoranda. Programa de Pós-graduação em Medicina Veterinária - PPGMV, Universidade Federal de Campina Grande - UFCG, Campus de Patos, Patos, PB, Brasil

${ }^{2}$ Médicos veterinários, MScs. Programa de Pós-graduação em Medicina Veterinária - PPGMV, Universidade Federal de Campina Grande - UFCG, Campus de Patos, Patos, PB, Brasil

${ }^{3}$ Médica veterinária, MSc, Residente de Anestesiologia Veterinária. Universidade Federal de Campina Grande - UFCG, Campus de Patos, Patos, PB, Brasil

${ }^{4}$ Médica veterinária autônoma. Patos, PB, Brasil

${ }^{5}$ Médico veterinário. Programa de Pós-Graduação em Medicina Veterinária - PPGMV, Universidade Federal de Campina Grande - UFCG, Campus de Patos, Patos, PB, Brasil

${ }^{6}$ Médicos veterinários, DScs. Unidade Acadêmica de Medicina Veterinária - UAMV, Universidade Federal de Campina Grande UFCG, Campus de Patos, Patos, PB, Brasil

\begin{abstract}
The analgesia and cardiopulmonary changes provided by methadone or morphine, by epidural route, were compared in female dogs undergoing to ovariohysterectomy. Sixteen female dogs were distributed into two groups, which received $0.3 \mathrm{mg} / \mathrm{kg}$ of methadone (MET group) or $0.1 \mathrm{mg} / \mathrm{kg}$ of morphine (MORPH group), both by lumbosacral epidural route. The anesthesia was maintained with isoflurane. Heart and respiratory rates, body temperature, systolic, mean and diastolic arterial pressure, cortisol and analgesia were evaluated. The analgesia was measured by numerical descriptive scale which has as a maximum score 25 points. In case a score superior to 16 was detected, morphine was administered $(0.5 \mathrm{mg} / \mathrm{kg}, \mathrm{IM})$. The following moments were considered: before and 15 minutes after the pre-anesthetic medication (MO e M1); 15, 50, 55, 65 and 95 minutes after the epidural puncture (M2, M3, M4, M5 and M6, respectively); 2, 4, 7, 13, 19 and 25 hours (M7, M8, M9, M10, M11 and M12, respectively) after the epidural puncture. The cortisol was measured before the measurement of the physiological parameters, in the moments MO, M3, M4, M8, M10 and M12. A reduction in the respiratory rate and decrease of body temperature occurred in both groups. Cortisol increased in the MORPH group at the clamping of the ovarian pedicles $(6.10 \pm 1.85 \mu \mathrm{g} / \mathrm{dL})$ and in the MET group, four hours after the epidural puncture $(9.05 \pm 7.77 \mathrm{mg} / \mathrm{dL})$, but none of the animals needed rescue analgesia and the analgesia was intense in both groups. Morphine and methadone have similar analgesic efficacy, and do not cause significant cardiopulmonary changes.
\end{abstract}

Keywords: canine, cortisolemia, pain.

\section{Resumo}

Foram comparadas a analgesiae as alterações cardiopulmonares promovidas pela metadona ou morfina, por via epidural, em cadelas submetidas à ovário-histerectomia. Dezesseis cadelas foram distribuídas dentro de dois grupos os quais receberam 0,3 mg/kg de metadona (grupo MET) ou 0,1 mg/kg de morfina (grupo MORF), ambas por via epidural lombossacra. A anestesia foi mantida com isoflurano. Foram avaliados: frequências cardíaca e respiratória, temperatura corporal, pressão arterial sistólica, média e diastólica, cortisol eanalgesia. A analgesia foi mensurada por escala descritiva numérica a qual possui um escore máximo de 25 pontos. Se um escore superior a 16 fosse detectado, seria administrada morfina $(0,5 \mathrm{mg} / \mathrm{kg}$, via IM). Os seguintes momentos foram considerados: antes e 15 minutos após a medicação pré-anestésica (M0 e M1); 15, 50, 55, 65 e 95 minutos após a punção epidural (M2, M3, M4, M5 e M6, respectivamente); 2, 4, 7, 13, 19 e 25 horas (M7, M8, M9, M10, M11 e M12, respectivamente) após a punção epidural. O cortisol foi mensurado antes da mensuração dos parâmetros fisiológicos, nos momentos MO, M3, M4, M8, M10 e M12. Ocorreu redução da frequência respiratória e da temperatura corporal em ambos os grupos. Cortisol aumentou no grupo MORF no pinçamento dos pedículos ovarianos $(6,10 \pm 1,85 \mu \mathrm{g} / \mathrm{dL})$ e no grupo MET, quarto horas após a
How to cite: Henrique, F. V., Parentoni, R. N., Medeiros, L. K. G., Brasil, A. W. L., Oliveira, K. D. S. Rego, R. O., Souza, A. P., \& Nóbrega Neto, P. I. (2017). Preoperative epidural administration of morphine or methadone for analgesia in female dogs undergoing to ovariohysterectomy. Brazilian Journal of Veterinary Medicine, 39(1), 46-53. doi: 10.29374/2527-2179.bjvm0253

Financial support: RNP and AWLB have a Capes scholarship.

Conflict of interests: No conflict of interests declared concerning the publication of this article.

Received: December 09, 2015.

Accepted: September 01, 2016.

The study was carried out at Universidade Federal de Campina Grande - UFCG, Patos, PB, Brasil.

\section{*Correspondence}

Fernanda Vieira Henrique

Programa de Pós-Graduação em Medicina Veterinária - PPGMV, Universidade Federal de Campina Grande - UFCG

Rua Dr. José Genuíno, 361, Ap. 303, Centro CEP 58700-050 - Patos (PB), Brasil E-mail: nandinhavh@gmail.com

Copyright Henrique et al. This is an Open Access article distributed under the terms of the Creative Commons Attribution Non-Commercial License which permits unrestricted non-commercial use, distribution, and reproduction in any medium provided the original work is properly cited. 
punção epidural $(9,05 \pm 7,77 \mathrm{mg} / \mathrm{dL}$ ), porém nenhum dos animais necessitou de analgesia de resgate, sendo a analgesia classificada como intensa em ambos os grupos. Morfina e metadona têm eficácia analgésica similar e não causam alterações cardiopulmonares significativas.

Palavras-chave: canino, cortisolemia, dor.

\section{Introduction}

Prevention of surgical pain by administration of analgesics attenuates central sensitization induced by nociceptive stimuli, reduces the amount of anesthetics required for maintenance of the anesthesia and results in smoother anesthetic recovery (Brondani et al., 2003). Compared to parenteral routes, epidural administration of opioids has overall benefits due to the proximity of the drug to the effector site, resulting in a more pronounced and prolonged effect. Furthermore, a smaller dose is necessary to promote analgesia, when liposoluble opioids are used, reducing the adverse effects, such as bradycardia and respiratory depression (Valadão et al., 2002). There is also a reduction in the concentration of the inhalation anesthetics required for the maintenance of the anesthesia and in the need of post-operative analgesia (Leibetseder et al., 2006).

Morphine is a pure $\mu$ agonist which promotes, by epidural route, sedation and reduction of the cortisol levels in dogs (Pereira \& Marques, 2009). The recommended dose is of $0.1 \mathrm{mg} / \mathrm{kg}$, and the analgesic effect starts 20 to 60 minutes after the epidural administration and lasts from eight to 24 hours (Jones, 2001), and may cause respiratory depression, pruritus, vomiting and urinary retention (Valadão et al., 2002). Morphine, in the dose of $0.1 \mathrm{mg} / \mathrm{kg}$, by epidural route, inhibited the increase in serum cortisol and the need for rescue analgesia, during 12 post-operative hours in female dogs undergoing to ovariohysterectomy (Neves et al., 2012).

Methadone is an opioid which presents agonist action in $\mu$ receptors and affinity with N-methyl-D-aspartate receptors. Its liposolubility favors a rapid epidural absorption (Campagnol et al., 2012). Its latency is of 10 minutes and the duration of analgesia is of seven hours, for a dose of $0.3 \mathrm{mg} / \mathrm{kg}$, in dogs (Leibetseder et al., 2006). An application by epidural route of methadone, in the dose of $0.5 \mathrm{mg} / \mathrm{kg}$, reduced the minimum alveolar concentration of isoflurane in dogs (Campagnol et al., 2012).

The present study aimed to compare the analgesia and the cardiopulmonary effects induced by epidural administration of methadone or morphine during intraoperative and postoperative periods in female dogs undergoing to elective ovariohysterectomy. We hypothesized that the methadone causes better analgesia through this route with fewer adverse effects.

\section{Material and methods}

This study was approved by the Ethics Committee in the Use of Animals of the institution of origin (protocol n $41 / 2012$ ).

Sixteen healthy crossbred female dogs, aged $3.4 \pm 2.6$ years and weighing $14.33 \pm 2.78 \mathrm{~kg}$ were used. After 12 hour-food fast and four hour-water fast, the animals received $0.1 \mathrm{mg} / \mathrm{kg}$ of acepromazine $^{1}+0.3 \mathrm{mg} / \mathrm{kg}$ of midazolam² ${ }^{2} \mathrm{IM}$, as pre-anesthetic medication, in order to potentialize the sedative effect of the fenotiazine. Fifteen minutes later, propofol ${ }^{3}$, was administered IV, in dose-effect system, in order to obtain profound sedation, so as to perform the epidural puncture. The animals were positioned in sternum-abdominal decubitus in order to carry out the lumbosacral epidural puncture, which was confirmed by the observation of the aspiration of a drop of $\mathrm{NaCl} 0.9 \%{ }^{4}$ solution previously placed in the lumen of a Tuohy needle of appropriate gauge for the size of the animal. The epidural administration was performed by an experienced professional who had no previous knowledge of the protocol. The animals were maintained sedated in sternum-abdominal decubitus for 30 minutes. Aproximately 45 minutes after the epidural puncture, a new intravenous anesthetic induction with propofol, in dose-effect system, was performed, the animal was intubated and the surgical procedure was initiated according with methodology described by MacPhail (2013).

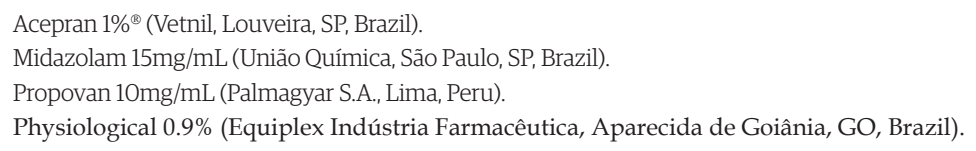


Two groups were randomly and equally formed, which received either $0.3 \mathrm{mg} / \mathrm{kg}$ of methadone ${ }^{5}$ (MET) or $0.1 \mathrm{mg} / \mathrm{kg}$ of morphine ${ }^{6}(\mathrm{MORPH})$. The opioid was diluted in $0.9 \% \mathrm{NaCl}$ for a volume of $0.25 \mathrm{~mL} / \mathrm{kg}$ and administered by epidural route. The anesthesia was maintained with isoflurane ${ }^{7}$ diluted in $100 \%$ of $\mathrm{O}_{2}$ in circular valvular circuit, supplied by means of a universal vaporizer and in spontaneous ventilation, in the $2^{\text {nd }}$ and $3^{\text {rd }}$ anesthetic plan. The following parameters were monitored: Heart rate (HR), in beats per minute, using a stethoscope ${ }^{8}$; respiratory rate (RR) by the observation of the thoracic movements during one minute (mpm); the body temperature (BT) measured with a clinical digital thermometer ${ }^{9}$ introduced into the animal's rectum; and the systolic arterial pressure (SAP) and diastolic (DAP) by non-invasive oscillometric method ${ }^{10}$. The pneumatic cuff was placed around of the middle region of the left radius and its width was equivalent to $40 \%$ of the circumference of this. In each experimental moment was performed three measurements of the arterial pressure, and the average value was obtained, which was recorded as the value for that moment. The mean arterial pressure (MAP) was calculated using the formula MAP = (SAP - DAP)/3 + DAP (Massone, 2011). The following moments were considered: before and 15 minutes after the pre-anesthetic medication (MO e M1); 15, 50, 55, 65 and 95 minutes after the epidural puncture (M2, M3, M4, M5 and M6, respectively); 2, 4, 7, 13, 19 and 25 hours (M7, M8, M9, M10, M11 and M12, respectively) after the epidural puncture. The moments M3, M4, M5 and M6 correspond to, respectively: three minutes after the dermotomy; three minutes after the clamping of the ovarian pedicles; three minutes after the clamping of the cervix; and one minute after the end of the surgery. All surgeries were performed by the same surgical team.

The total dose of propofol for the epidural puncture was measured, in $\mathrm{mg} / \mathrm{kg}$. For the determination of the serum cortisol, in $\mu \mathrm{g} / \mathrm{dL}$, blood samples ( $3 \mathrm{ml}$ ) were collected by puncture of the jugular vein, packed in sterilized test tubes without anticoagulant and centrifuged for 5 minutes at 5000 rotations by minute. The resulting serum was stored under refrigeration at $-20^{\circ} \mathrm{C}$. Serum cortisol was measured by electrochemiluminescence before the measurement of the physiological parameters, in the moments M0, M3, M4, M8, M1O and M12.

In the post-operative period the analgesia was evaluated, always by same trained observer, who was unfamiliar with the protocol used. For this purpose a numerical descriptive scale was used (Pibarot et al., 1997) (Table 1), which has as a maximum score 25 points. The analgesia was classified as being intense (scores of 0 to 8), moderate (scores of 9 to 16) or discreet (scores > 16). In case a score superior to 16 was detected, morphine would be administered (0.5 mg $/ \mathrm{kg}$, via IM).

For the comparison between the moments the two-tailed ANOVA test was used, followed by Tukey's test for samples with normal distribution or by the Friedman test for samples with not normal distribution. For the assessment of the analgesia U-Mann Whitney test was used. The comparison between the groups was analyzed using the $t$ student for samples with normal distribution or the U-Mann-Whitney test for samples with not normal distribution. In all the tests a 5\% significance was considered.

\section{Results and discussion}

The surgical time did not vary between the groups and was of 47.1 \pm 10.5 (average \pm standard deviation) and of $47.9 \pm 3.4$ minutes in the MET and MORPH groups, respectively.

There was no significant difference in the HR neither intra nor inter groups (Table2), suggesting that both the opioids used contributed to the autonomic stability of the animals. This fact is in accordance with Carregaro et al. (2014) who observed stability in this parameter when using morphine, in the dose of $0.1 \mathrm{mg} / \mathrm{kg}$, by epidural route in dogs submitted to thoracotomy, and with Bosmans et al. (2011) when using methadone, in the dose of $0.1 \mathrm{mg} / \mathrm{kg}$, by epidural route, in dogs anesthetized with isoflurane.

\footnotetext{
Mytedon 10mg/Ml (Cristalia Produtos Químicos Farmacêuticos Ltda., Itapira, SP, Brazil).

Dimorf 10 mg/mL (Cristalia Produtos Químicos Farmacêuticos Ltda., Itapira, SP, Brazil).

Isoflurane $100 \%$ (Rhodia, Itatiba, SP, Brazil).

Light weight littmann 3M stethoscope (Littmann, São Paulo, SP, Brazil).

Digital thermometer (G-Tech, São Paulo, SP, Brazil).

Veterinary non-invasive arterial pressure monitor (Delta Life, São José dos Campos, SP, Brazil).
} 
Table 1. Criteria for the assessment of the level of analgesia.

\begin{tabular}{|c|c|c|}
\hline PARAMETER & CRITERIA & SCORE \\
\hline \multirow{4}{*}{$\begin{array}{l}\text { Interactive } \\
\text { behavior }\end{array}$} & Atent and responds to human voice and touch & 0 \\
\hline & Responds timidly & 1 \\
\hline & Does not respond immediately & 2 \\
\hline & Does not respond or responds aggressively & 3 \\
\hline \multirow{4}{*}{$\mathrm{HR}, f, \mathrm{BP}$} & $</=10 \%$ higher than the preoperative value & 0 \\
\hline & 11 a 30\% higher than the preoperative value & 1 \\
\hline & 31 a 50\% higher than the preoperative value & 2 \\
\hline & $50 \%$ higher than the preoperative value & 3 \\
\hline \multirow{2}{*}{ Salivation } & Normal & 0 \\
\hline & Above normal & 1 \\
\hline \multirow{3}{*}{ Vocalization } & Without vocalization & 0 \\
\hline & Vocalization present e controlled without medication & 1 \\
\hline & Vocalization present and uncontrolled & 2 \\
\hline \multirow{4}{*}{ Agitation } & Asleep or calm & 0 \\
\hline & Light agitation & 1 \\
\hline & Moderate agitation & 2 \\
\hline & Severe agitation & 3 \\
\hline \multirow[b]{2}{*}{ Posture } & Sternal decubitus or moving calmly & 0 \\
\hline & $\begin{array}{l}\text { Defending and protecting the affected area, including fetal position, or } \\
\text { lateral decubitus }\end{array}$ & 1 \\
\hline \multirow{4}{*}{$\begin{array}{l}\text { Reaction to the } \\
\text { manipulation } \\
\text { of the surgical } \\
\text { wound }\end{array}$} & Without audible or visible reaction after 4 manipulations & 0 \\
\hline & Audible or visible reaction after the $4^{\text {th }}$ manipulation & 1 \\
\hline & Audible or visible reaction between the $2^{\text {nd }}$ and $3^{\text {rd }}$ manipulation & 2 \\
\hline & Audible or visible reaction in the $1^{\text {st }}$ manipulation & 3 \\
\hline \multirow{4}{*}{$\begin{array}{l}\text { Response to } \\
\text { manipulation }\end{array}$} & Without response & 0 \\
\hline & Minimum response, tries to avoid it & 1 \\
\hline & Turns head in the direction of the surgical wound, slight vocalization & 2 \\
\hline & Turns head with the intention of biting, severe vocalization & 3 \\
\hline
\end{tabular}

Source: adapted from Pibarot et al. (1997).

In MO was observed tachypnea in both groups (Table 2) due to the stress suffered during the measuring of the base parameters. From moment M3 up to M6 in the MORPH group and up to M5 no MET group there was as significant reduction in this parameter, this fact is due to the respiratory depression caused by the general anesthetics (Steffey et al., 1993) and opioids used (Valadão et al., 2002). In M4 the respiratory rate was significantly reduced in the MORPH group when compared to the MET group, demonstrating a greater respiratory depressant effect of morphine, probably, due to its hydrophilic property (Valadão et al., 2002). In the M12 the animals presented tachypnea due to the high temperature of the experimental kennels (about $35^{\circ} \mathrm{C}$ ), which are not air-conditioned, coinciding with the highest corporal temperature observed during the experimental period in both groups (Table 2).

There was a reduction of the BT from M2 in both groups, lasting up to two and four hours after epidural puncture in MET e MORPH groups, respectively (Table 2). This effect may be attributed to the thermolytic action of the opioids (Freitas et al., 2008), as well as to the heat loss caused by the opening of the abdominal cavity, the exposure to the low temperatures in the operating 


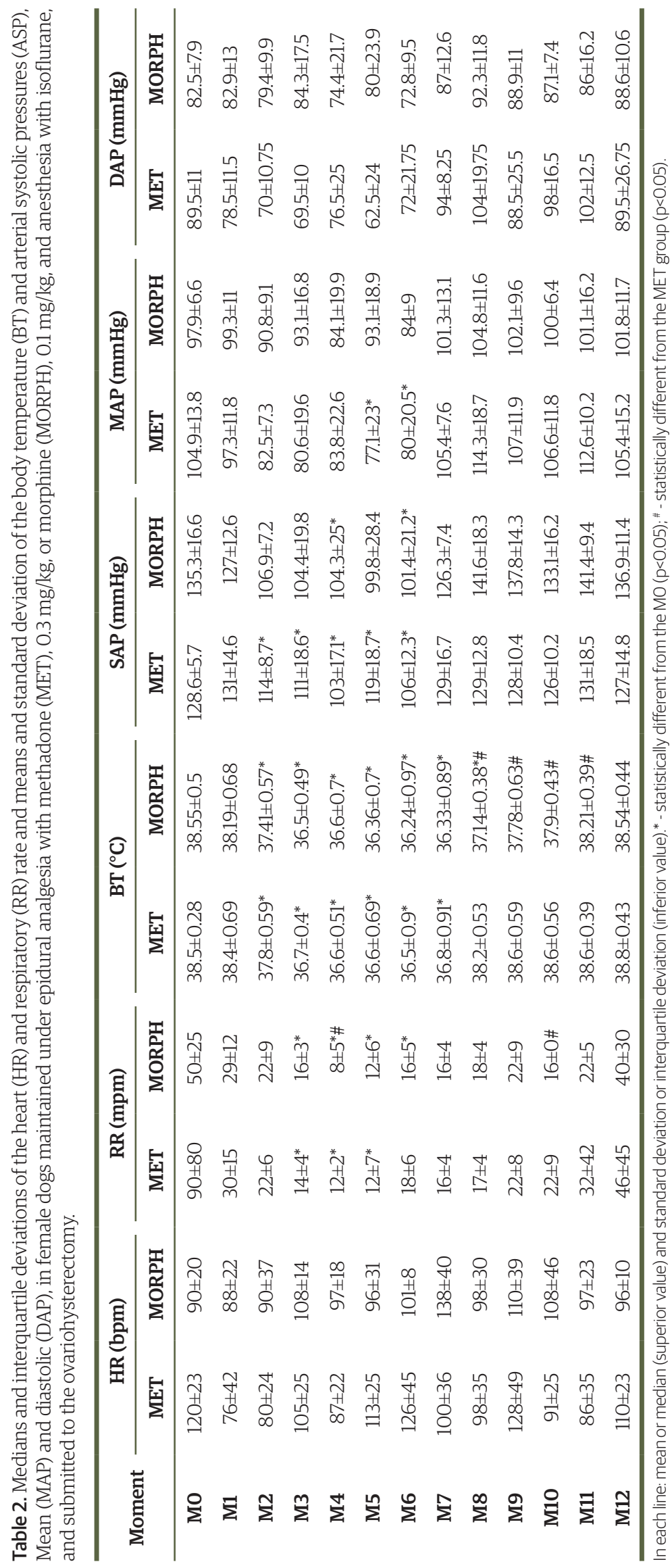


room, to the general anesthesia and the blood loss. There was statistical difference between the groups from M8 up to M11, eliciting morphine's greater hypothermizing effect.

Statistical differences were not verified between the groups regarding the SAP, MAP and DAP ( $>0.05$ ) (Table 2). The values of the SAP and DAP were elevated in the MO and in the post-operative period in both groups due to the stress caused by the physical restraint during the measurement of this parameter. In the MORPH group the SAP was reduced in the moments M4 and M6 and in the MET group from M2 until M6 when compared to the MO. Such reduction may be related to the analgesia promoted by the epidural, which abolished the neuroendocrine stimulation (Pereira \& Marques, 2009) promoted by the surgery. However, the SAP maintained itself above the values considered as being acceptable (SAP $\geq 90 \mathrm{mmHg}$ ) (Monteiro et al., 2008). There was a significant reduction in the MAP, in relation to the basal values, in the M5 and M6 in the MET group, however it maintained itself above $70 \mathrm{mmHg}$. There was no significant variation in the DAP both intra and inter groups, in agreement with Carregaro et al. (2014) who observed a stability in the arterial pressure after the administration of morphine in the dose of $0.1 \mathrm{mg} / \mathrm{kg}$, by epidural route in dogs.

There was no statistical difference between the groups ( $p>0.05$ ) regarding the requirement for propofol to perform the epidural puncture (MET - 3.19 $\pm 1.12 \mathrm{mg} / \mathrm{kg}$; MORPH - 3.01 $\pm 0.74 \mathrm{mg} / \mathrm{kg}$ ).

The cortisol increased significantly, in relation to the MO, in the MORPH group three minutes after the clamping of the ovarian pedicles, 55 minutes after the epidural puncture, (Table 3) due to the nociceptive stimulus arising from the traction and ligature of the ovarian pedicles (Malm et al., 2005), which were blocked only by methadone, probably due to morphine's long latency period by epidural route (Jones, 2001). In the $\mathrm{M} 8$ the cortisol levels were above the maximum limit for the species, which varies from 0.25 a $2.3 \mu \mathrm{g} / \mathrm{dL}$ (Russell et al., 2007) in both groups, but in the MET group these were statistically higher when compared to the MO and to the MORPH group (Table 3). The elevated cortisol levels in this moment may be attributed to the persistence of the nociceptive effects after the removal of the algic stimulus (Fox et al., 1998). The significant difference between the groups suggests a short analgesia validity period of methadone, as it is a lipophilic opioid (Campagnol et al., 2012). The cortisol remained increased, in relation to the physiological limits up to M9 (Table 3), however, it cannot be claimed that the animals were feeling pain once that the absence of pain was confirmed by the clinical evaluation of analgesia.

The pain scale used in the present study has been previously described for the quantification of pain in dogs (Pibarot et al., 1997; Neves et al., 2012). There was no significant difference in relation to the pain score, and the analgesia was classified as intense in all the moments in the two groups (Table 3). Thereby, none of the animals needed rescue analgesia, demonstrating that morphine and methadone have similar post-operative analgesic efficiency after ovariohysterectomy surgery in bitches.

In the post-operative period two animals presented vomiting in both groups, and one had excessive salivation in the MET group and five in the MORPH group. The salivation may be attributed to the opioids' parasympathomimetic action (Maiante et al., 2009). The vomiting is related to the activation of the chemoreceptor zone.

Table 3. Medians and interquartile deviations of the concentration serum cortisol and means and standard deviation of the analgesia scores in female dogs maintained under epidural analgesia with methadone (MET), $0.3 \mathrm{mg} / \mathrm{kg}$, or morphine (MORPH), 0.1 mg/kg, and anesthesia with isoflurane, and submitted to ovariohysterectomy.

\begin{tabular}{|c|c|c|c|c|c|c|c|c|c|c|}
\hline Variable & Group & MO & M3 & M4 & M7 & M8 & M9 & M10 & M11 & M12 \\
\hline \multirow{2}{*}{$\begin{array}{l}\text { Cortisol } \\
(\mu \mathrm{g} / \mathrm{dL})\end{array}$} & MET & $2.3 \pm 1.8$ & $2.0 \pm 4.5$ & $5.5 \pm 4.9$ & - & $9.0 \pm 7.7^{*}$ & - & $4.3 \pm 3.3$ & - & $2.0 \pm 0.9$ \\
\hline & MORPH & $2.2 \pm 1.1$ & $2.1 \pm 3.1$ & $6.1 \pm 1.8^{*}$ & - & $4.3 \pm 3.5 \#$ & - & $4.5 \pm 2.4$ & - & $2.0 \pm 2.9$ \\
\hline \multirow{2}{*}{ Scores } & MET & - & - & - & $4.4 \pm 2.8$ & $4.0 \pm 2.6$ & $4.4 \pm 3.3$ & $5.3 \pm 2.6$ & $4.3 \pm 2.8$ & $3.0 \pm 2.8$ \\
\hline & MORPH & - & - & - & $5.3 \pm 2.5$ & $4.9 \pm 3.1$ & $5.4 \pm 2.6$ & $4.9 \pm 1.4$ & $4.9 \pm 2.3$ & $4.6 \pm 2.9$ \\
\hline
\end{tabular}

* - statistically different from the MO ( $<<0,05)$; - statistically different from the MET group $(p<0,05)$. 


\section{Conclusions}

The findings suggest that morphine and methadone, in the doses used and by epidural route, have similar analgesic efficiency both in the trans and post-operative periods, and do not cause important cardiopulmonary alterations.

\section{References}

Bosmans, T., Schauvliege, S., Gasthuys, F., Duchateau, L., Marcilla, M. G., Gadeyne, C., \& Polis, I. (2011). Cardiovascular effects of epidural administration of methadone, ropivacaine 0,75\% and their combination in isofluorane anaesthetized dogs. Veterinary Anaesthesia and Analgesia, 38(2), 146-157. http://dx.doi.org/10.1111/j.14672995.2011.00595.x. PMid:21303446.

Brondani, J. T., Natalini, C. C., Schossler, J. E. W., Pinto Filho, S. T. L., \& Bertin, A. P. (2003). Alterações cardiovasculares de gatos submetidos à toracotomia intercostal, pré-medicados com associação de tramadol, burtofanol e atropina e anestesiados com propofol e halotano. Ciência Rural, 33(5), 869-873. http://dx.doi.org/10.1590/ S0103-84782003000500012.

Campagnol, D., Teixeira-Neto, F. J., Peccinini, R. G., Oliveira, F. A., Alvaides, R. K., \& Medeiros, L. Q. (2012). Comparison of the effects of epidural or intravenous methadone on the minimum alveolar concentration of isoflurane in dogs. Veterinary Journal (London, England), 192(3), 311-315. http://dx.doi.org/10.1016/j.tvjl.2011.08.019. PMid:21962818.

Carregaro, A. B., Freitas, G. C., Lopes, C., Lukarsewski, R., Tamiozzo, F. S., \& Santos, R. R. (2014). Evaluation of analgesic and physiologic effects of epidural morphine administered at a thoracic or lumbar level in dogs undergoing thoracotomy. Veterinary Anaesthesia and Analgesia, 41(2), 205-211. http://dx.doi.org/10.1111/ vaa.12105. PMid:24734296.

Fox, S. M., Mellor, D. J., Lawoko, C. R., Hodge, H., \& Firth, E. C. (1998). Changes in plasma cortisol concentrations in bitches in response to different combinations of halothane and butorphanol, with or without ovariohysterectomy. Research in Veterinary Science, 65(2), 125-133. http://dx.doi.org/10.1016/S0034-5288(98)90163-1. PMid:9839890.

Freitas, G. C., Carregaro, A. B., Lopes, C., Tamiozzo, F. S., Cruz, F. S. F., Festugatto, F., \& Mazzanti, A. (2008). Analgesia trans e pós-operatória da morfina ou fentanil por via epidural em cães submetidos à biópsia atlanto-axial. Ars Veterinária, 24, 103-109.

Jones, R. S. (2001). Epidural analgesia in the dog and cat. Veterinary Journal, 161(2), 123-131. http://dx.doi.org/10.1053/ tvjl.2000.0528. PMid:11243684.

Leibetseder, E. N., Mosing, M., \& Jones, R. S. (2006). A comparison of extradural and intravenous methadone on intraoperative isoflurane and postoperative analgesia requirements in dogs. Veterinary Anaesthesia and Analgesia, 33(2), 128-136. http://dx.doi.org/10.1111/j.1467-2995.2005.00239.x. PMid:16476003.

Macphail, C. M. Surgery of the reproductive and genital systems. In T. W. Fossum, C.W. Dewey, C. V. Horn, A. L. Johnson, C.M. MacPhail, M.G. Radlinsky, K.S. Schulz \& M.D. Willard (Eds), Small Animal Surgery. (4th ed., pp. 780-853). St. Louis: Elsevier, 2013.

Maiante, A. A., Teixeira Neto, F. J., Beier, S. L., Corrente, J. E., \& Pedroso, C. E. (2009). Comparison of the cardiorespiratory effects of methadone and morphine in conscious dogs. Journal of Veterinary Pharmacology and Therapeutics, 32(4), 317-328. http://dx.doi.org/10.1111/j.1365-2885.2008.01042.x. PMid:19614836.

Malm, C., Savassi-Rocha, P. R., Gheller, V. A., Oliveira, H. P., Lamounier, A. R., \& Foltynek, V. (2005). Ováriohisterectomia: estudo experimental comparativo entre as abordagens laparoscópica e aberta na espécie canina. II-Evolução clínica pós-operatória. Arquivo Brasileiro de Medicina Veterinária e Zootecnia, 57(Suppl 2), 162-172. http://dx.doi.org/10.1590/S0102-09352005000800006.

Massone F. (2011). Anestesiologia Veterinária - Farmacologia e técnicas, texto e atlas (6. ed., 448 p.). Rio de Janeiro: Guanabara Koogan.

Monteiro, E. R., Dossi, R. J. O., Antunes, A. P., Campagnol, D., Bettini, C. M., \& Choma, J. C. (2008). Efeitos da metadona ou do neostigmine, associados à lidocaína administrados pela via epidural em cães. Arquivo Brasileiro de Medicina Veterinária e Zootecnia, 60(6), 1439-1446. http://dx.doi.org/10.1590/\$0102-09352008000600020.

Neves, C. S., Balan, J. A., Pereira, D. R., Stevanin, H., \& Cassu, R. N. (2012). A comparison of extradural tramadol and extradural morphine for postoperative analgesia in female dogs undergoing ovariohysterectomy. Acta Cirurgica Brasileira, 27(4), 312-317. http://dx.doi.org/10.1590/S0102-86502012000400006. PMid:22534806.

Pereira, D. A., \& Marques, J. A. (2009). Uso de morfina, xilazina e meloxicam para o controle da dor pós-operatória em cadelas submetidas à ovariossalpingo-histerectomia. Arquivo Brasileiro de Medicina Veterinária eZootecnia, 61(2), 353-361. http://dx.doi.org/10.1590/S0102-09352009000200011.

Pibarot, P., Dupuis, J., Grisneaux, E., Cuvelliez, S., Planté, J., Beauregard, G., Bonneau, N. H., Bouffard, J., \& Blais, D. (1997). Comparison of ketoprofen, oxymorphone hydrochloride, and butorphanol in the treatment of postoperative pain in dogs. Journal of the American Veterinary Medical Association, 211(4), 438-444. PMid:9267504.

Russell, N. J., Foster, S., Clark, P., Robertson, I. D., Lewis, D., \& Irwin, P. J. (2007). Comparison of radioimmunoassay and chemiluminescent assay methods to estimate canine blood cortisol concentrations. Australian Veterinary Journal, 85(12), 487-494. http://dx.doi.org/10.1111/j.1751-0813.2007.00232.x. PMid:18042154. 
Steffey, E. P., Eisele, J. H., Baggot, J. D., Woliner, M. J., Jarvis, K. A., \& Elliott, A. R. (1993). Influence of inhaled anesthetics on the pharmacokinetics and pharmacodynamics of morphine. Anesthesia and Analgesia, 77(2), 346-351. http://dx.doi.org/10.1213/00000539-199377020-00023. PMid:8346837.

Valadão, C. A. A., Duque, J. C., \& Farias, A. (2002). Administração epidural de opióides em cães. Ciência Rural, 32(2), 347-355. http://dx.doi.org/10.1590/S0103-84782002000200028. 